Number 4

\title{
EFEKTIVITAS EKSTRAK KAPANG ENDOFIT ISOLAT BR-S (A) TERHADAP BAKTERI Methicillin-Resistant Staphylococcus aureus
} (MRSA)

\author{
Kurniawan $^{1, *)}$ and Nuniek Ina Ratnaningtyas ${ }^{2}$ \\ ${ }^{1}$ Medical Laboratory Technology Study Program (Undergraduate) of Universitas Muhammadiyah \\ Purwokerto \\ ${ }^{2}$ Biology Study Program (Undergraduate) of Universitas Jenderal Soedirman Purwokerto \\ *email: kurniawan@ump.ac.id
}

\begin{abstract}
Background Tea parasitic plant (Scurrulaoortiana L.) is one of medicinal plants (herbamedicina) containing several active compounds but its utilization is still constrained by some problems, so that thereneeds other approaches by utilizing potential of BR-S1 (A) isolate endophytic fungi which grows in these plants to control MRSA pathogenic bacteria. ObjectiveThis research aimed to examine the effectiveness of the four types of $B R-S_{1}(A)$ endophytic fungi extract from the origin of tea parasites to the growth of MRSA bacteria.

MethodsThe researchers used laboratory experimental method by Kirby Bauer disk diffusion method and the data obtained were analyzed statistically.

ResultThe research result showed that MRSA bacteria had various sensitivity on four types of BR-S1 (A) isolate endophytic fungi; with its highest sensitivity on extract of ethyl acetate and its lowest sensitivity was extract of n-hexane (no inhibition). The difference of sensitivity test results was suspected to be related to active compound content found in ethyl acetate extract in form of flavonoid and tannin class compounds which had been proven to inhibit growth of pathogenic bacteria.

ConclusionIt can be concluded that the four types of BR-S $S_{1}(A)$ endophytic fungus extract originating from tea parasites, only ethyl acetate extract was the most effective in inhibiting the growth of MRSA bacteria, this is due to the content of two active compounds from the flavonoid and tannin groups.
\end{abstract}

Keywords: ,endophytic fungus extract,tea parasitic plant, MRSA bacteria

\section{PENDAHULUAN}

Tumbuhan benalu teh (Scurrula oortiana L.) merupakan salah satu jenis tumbuhan obat (herba medicinal) yang mengandung beberapa senyawa aktif seperti golongan flavonoid, alkaloid, glikosida, triterpen, saponin, dan $\operatorname{tanin}^{1}$. Namun dalam pemanfaatannya masih terkendala oleh ketersediaannya di alam yang terbatas dan proses ekstraksinya yang relatif sulit dan kompleks.

Berkaitan dengan hal tersebut di atas, maka perlu ada pendekatan lain dengan memanfaatkan kapang endofit yang hidup pada tanaman benalu teh. Kapang endofit merupakan kapang yang seluruh atau sebagian dari siklus hidupnya dihabiskan dengan mengkolonisasi jaringan yang sehat dari tumbuhan inang baik secara interseluler

Meditory | ISSN Online : 2549-1520, ISSN Cetak : 2338 - 1159, Vol. 6, No. 2, Desember 2018 HIm. 99 - 107, http://ejournal.poltekkes-denpasar.ac.id/index.php/M 
maupun intraseluler tanpa menyebabkan penyakit dengan gejala yang nyata ${ }^{2}$.

Kapang endofit memiliki potensi yang sangat besar terkait dengan kemampuannya dalam menghasilkan berbagai senyawa aktif seperti senyawa antimikroba, antiimunosupresif, antidiabetik, antikanker, antiinsektisidal, dan antiviral dalam kisaran yang luas. Senyawa antimikroba yang dihasilkan oleh kapang endofit telah banyak dimanfaat dalam praktik pengobatan untuk menekan pertumbuhan bakteri patogen.

Bakteri patogen Methicillin-Resistants Saphylococcus aureus (MRSA) merupakan salah satu jenis bakteri patogen yang telah menjadi perhatian utama karena memiliki ketahanan atau resistensi terhadap kelompok antibiotik beta laktam. Penyebaran yang semakin luas dari bakteri ini telah menimbulkan kekhawatiran dan ketakutan pada masyarakat luas sehingga diperlukan suatu cara atau strategi khusus dengan memanfaatkan potensi yang dimiliki oleh kapang endofit tumbuhan benalu teh dalam menghasilkan senyawa antimikroba.

Isolat BR-S ${ }_{1}$ (A) merupakan salah satu jenis kapang endofit yang diperoleh dari bagian batang tanaman benalu teh dan berdasarkan hasil identifikasi termasuk dalam spesies Helicodendron sp. Hasil penelitian sebelumnya menunjukkan bahwa ekstrak kasar dari kapang endofit isolat BR-
$\mathrm{S}_{1}$ (A) ini mampu menghambat pertumbuhan beberapa jenis bakteri patogen yang tidak resisten terhadap antibiotik. Bagaimana ekstrak kapang endofit isolat BR-S $\mathrm{S}_{1}$ (A) dalam menghambat pertumbuhan bakteri patogen MRSA itu belum ada informasinya sehingga perlu untuk dipelajari atau diteliti terlebih dahulu.

Penelitian ini bertujuan untuk mengkaji keefektifan keempat jenis ekstrak kapang endofit isolat ${\mathrm{BR}-\mathrm{S}_{1}}_{1}$ (A) asal tumbuhan benalu teh terhadap pertumbuhan bakteri MRSA. Hipotesis yang diajukan dalam penelitian ini menyatakan bahwa bakteri MRSA sensitif terhadap ekstrak kapang endofit isolat ${\mathrm{BR}-\mathrm{S}_{1}}$ (A) asal tumbuhan benalu teh.

\section{METODE}

Sampel tumbuhan benalu teh ( $S$. oortiana L.) diperoleh dari perkebunan milik Pemerintah dan juga milik masyarakat di Dusun Purwodadi, Desa Cendana, Kecamatan Kutasari, Kabupaten Purbalingga Jawa Tengah. Kultur murni bakteri Methicillin-Resistant Staphylococcus aureus (MRSA) diperoleh dari Laboratorium Mikrobiologi Fakultas Biologi UNSOED.

\section{a Kultivasi Skala Mikro Kapang Endofit Isolat BR-S (A)}

Kultur murni kapang endofit isolat BR-S $_{1}$ (A) pertama-tama ditumbuhkan pada medium PDA cawan dan diinkubasi 
selama 7-14 hari pada suhu ruang. Medium PDA cawan yang telah ditumbuhi oleh kapang endofit tersebut kemudian dicuplik sebanyak 3 kali menggunakan bor gabus berdiameter 0,5 cm untuk diinokulasikan ke dalam $200 \mathrm{ml}$ medium PDB steril. Medium PDB tersebut selanjutnya diinkubasi dengan cara diagitasi menggunakan rotary shaker pada kecepatan $\pm 100 \mathrm{rpm}$ selama 14 hari pada suhu ruang.

b Seleksi Awal (Screening) Kemampuan Kapang Endofit Isolat BR-S1 (A) dalam Menghasilkan Senyawa Antimikroba

Disiapkan medium PCA cawan yang sebelumnya telah diinokulasikan dengan $1 \mathrm{ml}$ bakteri MRSA overnight dan dibiarkan sampai memadat. $\mathrm{Ke}$ atas medium tersebut selanjutnya diletakkan sebanyak 5 buah kertas cakram steril berdiameter $6 \mathrm{~mm}$ yang masing-masing ditetesi dengan $20 \mu \mathrm{l}$ filtrat kapang endofit (3 kertas cakram), akuades steril (1 kertas cakram), dan antibiotik kloramfenikol (1 kertas cakram) dengan konsentrasi 25 $\mathrm{mg} / \mathrm{ml}$. Medium PCA cawan selanjutnya diinkubasi pada suhu $37{ }^{\circ} \mathrm{C}$ selama $1-2 \mathrm{x}$ 24 jam dan diamati ada tidaknya zona hambat (zona bening) yang terbentuk di sekitar kertas cakram. Zona hambat yang terbentuk selanjutnya diukur diameternya menggunakan jangka sorong dan begitu juga dengan diameter kertas cakram yang digunakan. Berdasarkan data diameter tersebut dilakukan penghitungan luas zona hambat menggunakan rumus sebagai berikut:

$$
\begin{gathered}
\mathrm{L}_{\text {zhaw }}: \pi \cdot \mathrm{r}_{\mathrm{a}}^{2} \quad \mathrm{~L}_{\mathrm{kc}}: \pi \cdot \mathrm{r}_{\mathrm{b}}{ }^{2} \\
\mathrm{~L}_{\text {zhak }}: \mathrm{L}_{\text {zhaw }}-\mathrm{L}_{\mathrm{kc}}
\end{gathered}
$$

Keterangan:

$\mathrm{r}_{\mathrm{a}} \quad$ : Jari-jari zona hambat $(\mathrm{mm})$

$\mathrm{r}_{\mathrm{b}} \quad$ : Jari-jari kertas cakram $(\mathrm{mm})$

$\mathrm{L}_{\text {zhaw }}$ : Luas zona hambat awal $\left(\mathrm{mm}^{2}\right)$

$\mathrm{L}_{\mathrm{kc}} \quad$ : Luas kertas cakram $\left(\mathrm{mm}^{2}\right)$

$\mathrm{L}_{\text {zhak }}$ : Luas zona hambat akhir $\left(\mathrm{mm}^{2}\right)$

$\pi \quad: 3,14$

\section{c Kultivasi Skala Makro Kapang Endofit} Isolat BR-S1 (A)

Kapang endofit hasil seleksi awal selanjutnya diperbanyak dengan cara ditumbuhkan pada beberapa medium PDA cawan dan diinkubasi pada suhu ruang selama 7-14 hari. Setelah medium PDA cawan dipenuhi dengan miselium kapang, medium kemudian dicuplik menggunakan bor gabus dan diinokulasikan (3-5 cuplikan) ke dalam $200 \mathrm{ml}$ medium PDB pada beberapa Erlenmeyer berukuran 250 ml. Medium tersebut kemudian diinkubasi pada suhu ruang selama 14 hari dengan dilakukan agitasi menggunakan rotary shaker berkecepatan $\pm 100 \mathrm{rpm}$.

Meditory | ISSN Online : 2549-1520, ISSN Cetak : 2338 - 1159, Vol. 6, No. 2, Desember 2018 HIm. 99 - 107, http://ejournal.poltekkes-denpasar.ac.id/index.php/M 
d Ekstraksi Kapang Endofit Tumbuhan Benalu Teh

Hasil kultivasi skala makro terlebih dahulu disaring menggunakan kertas saring sehingga diperoleh miselium dan filtrat. Miselium yang diperoleh selanjutnya ditimbang dan dikeringkan pada oven bersuhu $50{ }^{\circ} \mathrm{C}$ selama $2 \times 24$ jam. Setelah kering selanjutnya ditimbang dan dibuat ekstrak methanol dengan cara direndam dalam pelarut metanol (1:10 $\mathrm{g} / \mathrm{v})$ selama 7-10 hari dan diulang sebanyak 3 kali. Filtrat hasil penyaringan selanjutnya juga diekstraksi secara maserasi menggunakan tiga jenis pelarut organik yang berbeda yaitu n-hexan, etilasetat, dan etanol 96\% (1:1 v/v) selama 7-10 hari sambil digojok di atas rotary shaker berkecepatan 100 rpm. Ekstraksi diulang sebanyak 3 kali (khusus untuk etanol 96\% hanya sekali) dan setiap hasil ekstraksi selanjutnya dievaporasi menggunakan rotary evaporator pada suhu $50{ }^{\circ} \mathrm{C}$ dengan kecepatan $60 \mathrm{rpm}$ sampai diperoleh ekstrak dalam bentuk pasta.

\section{e Preparasi Bakteri Uji MRSA}

Preparasi inokulum bakteri uji dilakukan dengan metode Standard Plate Count (SPC). Diambil sebanyak $1 \mathrm{ml}$ stok bakteri MRSA untuk ditambahkan ke dalam $25 \mathrm{ml}$ medium Nutrient Broth (NB) steril dan dishaker pada kecepatan 100 rpm selama 1 x 24 jam pada suhu $37^{\circ} \mathrm{C}$. Dari medium NB ini dilakukan pengenceran sampai tingkat pengenceran $10^{-7}$ dengan dua pengenceran terakhir dilakukan plating secara duplo menggunakan metode pour plate pada medium PCA. Setelah itu medium PCA diinkubasi selama 1 x 24 jam pada suhu $37{ }^{\circ} \mathrm{C}$ dan dihitung jumlah koloni yang tumbuh pada setiap cawan petri.

f Uji Sensitivitas Bakteri MRSA Terhadap Ekstrak Kapang Endofit Isolat BR-S1 (A)

Diambil sebanyak $1 \mathrm{ml}$ suspensi bakteri MRSA dengan konsentrasi $10^{5}$ CFU/ml untuk dicampur dengan $15 \mathrm{ml}$ medium PCA (suhu $40-45^{\circ} \mathrm{C}$ ) dan dituang ke dalam cawan petri steril. Medium kemudian digerak-gerakkan membentuk angka 8 sehingga suspensi bakteri menjadi homogen dan rata sempurna. Setelah memadat, di atas medium tersebut diletakkan kertas cakram steril berdiameter $6 \mathrm{~mm}$ sebanyak 6 buah yang masing-masing ditetesi dengan $20 \mu \mathrm{l}$ ekstrak n-heksana, etilasetat, etanol 96\%, dan metanol (4 kertas cakram), akuades steril sebagai control negatif (1 kertas cakram), dan antibiotik vankomisin sebagai kontrol positif (1 kertas cakram). Medium PCA selanjutnya diinkubasi selama $1-2$ x 24 jam pada suhu $37{ }^{\circ} \mathrm{C}$ dan setelah itu diamati ada tidaknya zona 
hambat di sekitar kertas cakram. Apabila terbentuk zona hambat, maka dilakukan pengukuran diameter dan penghitungan luas zona hambat menggunakan rumus seperti di atas

g Analisis Hasil Uji Sensitivitas Bakteri MRSA Terhadap Ekstrak Kapang Endofit Isolat BR-S1 (A)

Data hasil uji sensitivitas ekstrak kapang endofit isolat BR-S 1 (A) terhadap bakteri MRSA dianalisis menggunakan metode Analisis Varian (ANAVA) pada taraf kepercayaan $95 \%$. Apabila hasil analisis ANAVA menunjukkan hasil yang berbeda nyata, maka analisis dilanjutkan dengan Duncan's Multiple Range Test (DMRT) pada taraf kepercayaan $95 \%$.

\section{HASIL DAN PEMBAHASAN}

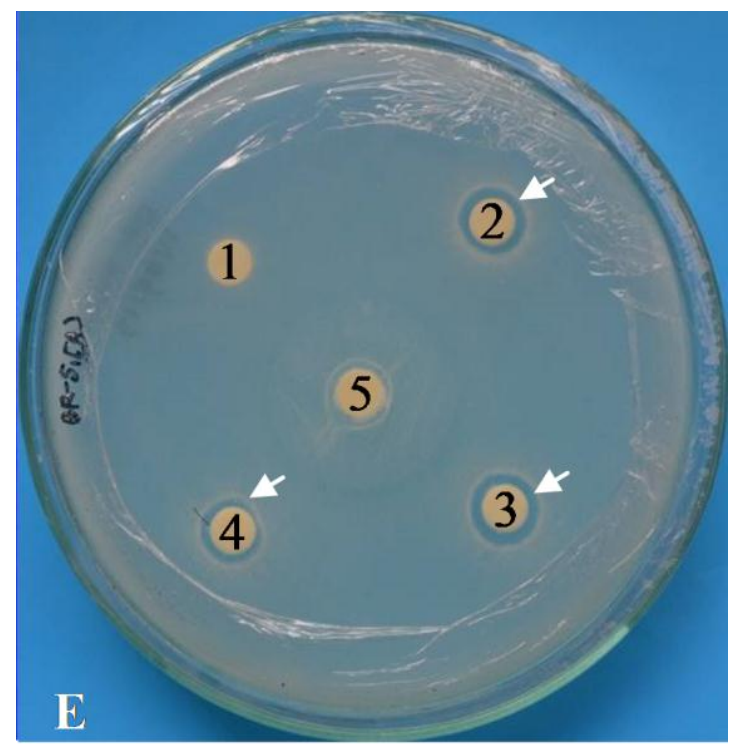

Gambar 1. Luas zona hambat uji sensitivitas bakteri MRSA terhadap ekstrak kasar kapang endofit isolat BR-S $\mathrm{S}_{1}(\mathrm{~A})$

Keterangan:

1: Kontrol negatif (akuades)

2: Ulangan ke-1,

3: Ulangan ke-2,

4: Ulangan ke-3

5: Kontrol positif (kloramfenikol)
Seleksi awal (screening) kemampuan kapang endofit isolat $\mathrm{BR}^{-\mathrm{S}_{1}}$ (A) dalam menghasilkan senyawa antimikroba dilakukan menggunakan metode difusi agar. Berdasarkan hasil pengamatan diperoleh data bahwa ekstrak kasar kapang endofit isolat BR-S 1 (A) mampu menghasilkan senyawa antimikroba yang efektif menghambat bakteri MRSA.

Berdasarkan Gambar 1 dan Tabel 1 dapat diketahui bahwa ekstrak kasar kapang endofit isolat $\mathrm{BR}^{-\mathrm{S}_{1}}$ (A) mampu menghambat pertumbuhan bakteri MRSA dengan rerata luas zona hambat mencapai $28,54 \mathrm{~mm}^{2}$. Hasil pengujian kapang endofit isolat BR-S 1 (A) memiliki ekstrak kasar yang setelah diteteskan di atas kertas cakram dapat terserap sempurna dan tidak ada yang menyebar sehingga zona hambat yang terbentuk di sekitar kertas cakram juga sangat jelas terlihat.

Ekstrak kasar kapang endofit isolat BR-S S $_{1}$ (A) atau Helicodendron sp. mampu menekan pertumbuhan bakteri MRSA dengan rerata luas zona hambat mencapai

Tabel 1. Hasil perhitungan luas zona hambat uji sensitivitas bakteri MRSA terhadap ekstrak kasar kapang endofit isolat BR-S (A)

\begin{tabular}{lc}
\hline & Luas Zona Hambat $\left(\mathbf{m m}^{\mathbf{2}}\right)$ \\
\hline $\mathbf{U}_{\mathbf{1}}$ & 28,46 \\
$\mathbf{U}_{\mathbf{2}}$ & 33,92 \\
$\mathbf{U}_{\mathbf{3}}$ & 23,24 \\
$\mathbf{K}(-)$ & 0 \\
$\mathbf{K}(+)$ & 0 \\
Jumlah & 85,62 \\
Rerata $\left(\mathbf{m m}^{\mathbf{2}}\right)$ & 28,54 \\
\hline
\end{tabular}

Keterangan:

$\mathrm{U}_{1}$ : Ulangan ke-1, $\quad \mathrm{U}_{2}$ :Ulangan ke-2,

$\mathrm{U}_{3}$ : Ulangan ke-3, $\quad \mathrm{K}(-)$ : Akuades steril K (+): Kloramfenikol 


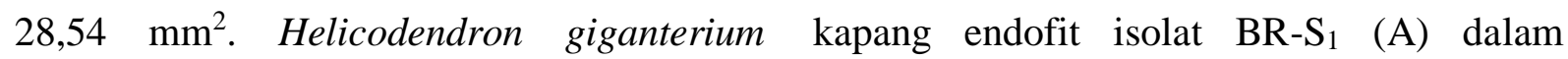
merupakan salah satu anggota genus menekan pertumbuhan bakteri MRSA Helicodendron yang memiliki kemampuan menunjukkan hasil yang bervariasi. Data menghasilkan 3 tipe senyawa aktif yang lengkap mengenai keefektifan senyawa dikenal sebagai heliconol $A, B$, dan $C$. antimikroba dari ke-4 jenis ekstrak kapang Senyawa heliconol A memiliki fungsi sebagai endofit tersebut disajikan pada Gambar 2 dan senyawa antibakteri terhadap B. subtilis dan Tabel 2.

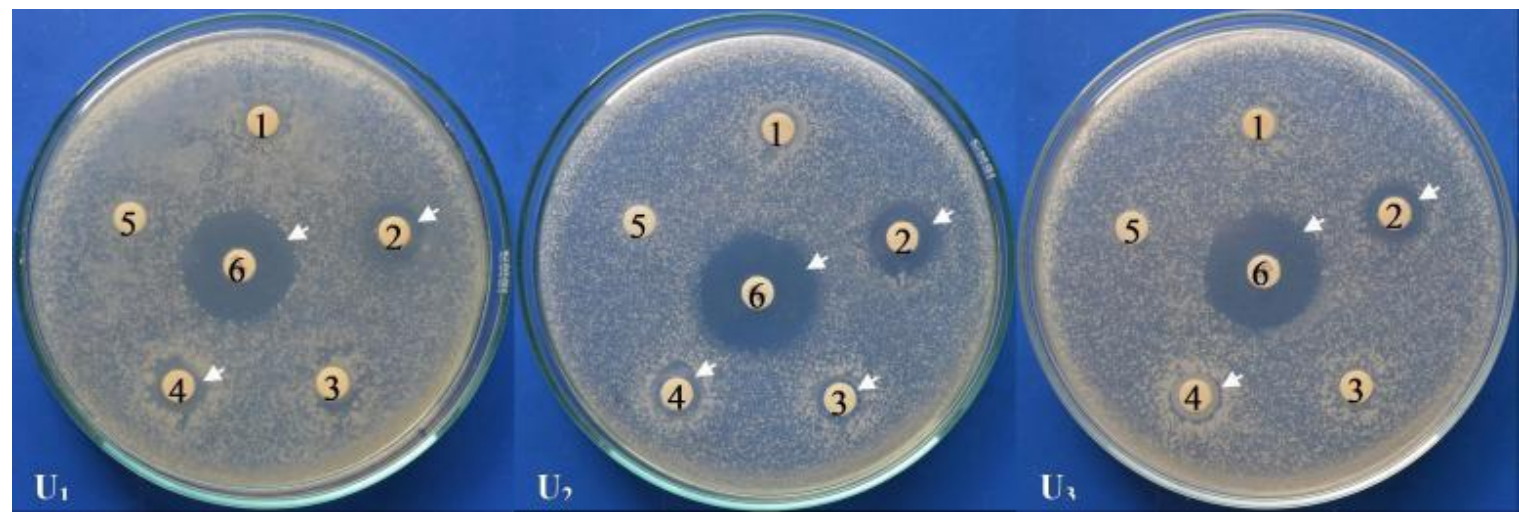

Gambar 2. Hasil uji sensitivitas bakteri MRSA terhadap keempat jenis ekstrak kapang endofit isolat $\mathrm{BR}-\mathrm{S}_{1}(\mathrm{~A})$

$\begin{array}{llll}\text { Keterangan: } & \mathrm{U}_{1} \text { : Ulangan ke-1, } & \mathrm{U}_{2}: \text { Ulangan ke-2, } & \mathrm{U}_{3} \text { : Ulangan ke-3, } \\ & \text { 1: Ekstrak n-heksana } & \text { 2: Ekstrak etil asetat } & \text { 3: Ekstrak etanol } 96 \% \\ \text { 4: Ekstrak metanol } & \text { 5: Kontrol (-) } & \text { 6: Kontrol (+) }\end{array}$

Berdasarkan hasil seleksi awal tersebut, diketahui bahwa dari ke-4 jenis (screening) dan uji sensitivitas ekstrak kasar ekstrak kapang endofit isolat BR-S (A) $_{1}$

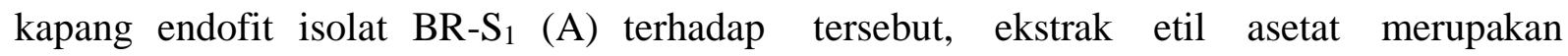
bakteri MRSA, maka pada tahap selanjutnya ekstrak yang paling efektif dalam menekan dilakukan ekstraksi kapang endofit ini pertumbuhan bakteri MRSA yang kemudian dengan menggunakan 4 jenis pelarut yang diikuti oleh ekstrak metanol, dan etanol 96\%. berbeda yaitu n-heksana, etil asetat, alkohol Pengujian ekstrak n-heksana dengan ulangan 96\% dan metanol. Hasil ekstraksi tersebut sebanyak 3 kali menunjukkan hasil yang selanjutnya juga digunakan untuk uji negatif dalam menekan pertumbuhan bakteri sensitivitas terhadap bakteri MRSA. MRSA.

Kemampuan senyawa antimikroba Adanya variasi pada hasil pengujian yang dihasilkan dari ke-4 jenis ekstrak dari ke-4 jenis ekstrak kapang endofit isolat 
Tabel 2. Hasil perhitungan luas zona hambat uji sensitivitas bakteri MRSA terhadap keempat jenis ekstrak kapang endofit isolat BR-S $\mathrm{S}_{1}(\mathrm{~A})$

\begin{tabular}{|c|c|c|c|c|c|c|}
\hline \multirow{2}{*}{ No } & \multirow{2}{*}{ JenisEkstrak } & \multicolumn{3}{|c|}{ Luas zona hambat $\left(\mathrm{mm}^{2}\right)$} & \multirow[t]{2}{*}{ Jumlah } & \multirow[t]{2}{*}{$\operatorname{Rerata}\left(\mathrm{mm}^{2}\right)$} \\
\hline & & $\mathbf{U}_{1}$ & $\mathbf{U}_{2}$ & $\mathbf{U}_{3}$ & & \\
\hline 1. & n-heksana & 0 & 0 & 0 & 0 & 0 \\
\hline 2. & Etilasetat & 55,02 & 82,9 & 55,02 & 192,94 & 64,31 \\
\hline 3. & Etanol 96\% & 0 & 0,95 & 0 & 0,95 & 0,31 \\
\hline 4. & Metanol & 8,038 & 10,21 & 39,63 & 57,87 & 19,29 \\
\hline 5. & Kontrol (-) & 0 & 0 & 0 & 0 & 0 \\
\hline 6. & Kontrol (-) & 311,4 & 376,2 & 344,8 & 1032,4 & 344,13 \\
\hline & Keterangan: & $\begin{array}{l}\mathrm{U}_{1} \text { : Ulanga } \\
\mathrm{K}(-) \text { : Aku }\end{array}$ & & $\begin{array}{l}\text { gan ke-2, } \\
\text { ankomisin }\end{array}$ & $\begin{array}{l}\mathrm{U}_{3} \text { : Ulan } \\
0 \text { : tidak }\end{array}$ & $\begin{array}{l}\text { ke-3, } \\
\text { penghambatan }\end{array}$ \\
\hline
\end{tabular}

$\mathrm{BR}-\mathrm{S}_{1}(\mathrm{~A})$ tersebut diduga berkaitan dengan senyawa aktif yang terkandung di dalam masing-masing ekstrak. Ekstrak etil asetat mampu menekan pertumbuhan bakteri MRSA karena memiliki kandungan senyawa aktif berupa senyawa flavonoid dan tanin (Tabel 3). Kedua senyawa aktif tersebut diduga memiliki kemampuan sebagai senyawa antimikroba yang dibuktikan dengan terbentuknya zona hambat di sekitar kertas cakram dengan rerata luas zona hambat mencapai $64,31 \mathrm{~mm}^{2}$. Ekstrak etil asetat dari kapang endofit Lecythophora sp. memiliki aktivitas antibakteri terhadap bakteri Gram positif dan negatif, hal ini diduga karena adanya kandungan senyawa kimia dengan struktur aromatis, polifenol, atau yang mirip dengan flavonoid ${ }^{4}$. Flavonoid dari tanaman Euphorbia hirta lebih efektif dalam menekan pertumbuhan bakteri Gram positif seperti $S$. aureus daripada terhadap bakteri Gram negatif 5 . Senyawa flavonoid dan tanin memiliki aktivitas antimikroba yang menyerang dinding sel, berikatan dengan adhesin, menghalangi enzim atau merusak membran ${ }^{6}$. Aktivitas antibakteri dari senyawa flavonoid dapat dilakukan melalui beberapa mekanisme yang diantaranya melalui proses penghambatan sintesis asam nukleat, penghambatan fungsi membran sitoplasma, dan penghambatan energi metabolisme ${ }^{7}$. Berbeda dengan senyawa flavonoid yang memiliki beberapa mekanisme antibakteri, senyawa tanin hanya memiliki 1 mekanisme aktivitas antibakteri yaitu melalui pengikatan protein-protein sel yang pada akhirnya akan menghalangi proses sintesis protein di dalam $\mathrm{sel}^{8}$.

Tabel 3. Hasil uji kualitatif kandungan senyawa aktif keempat jenis ekstrak kapang endofit isolat BR-S $\mathrm{S}_{1}$ (A)

\begin{tabular}{lcccc}
\hline \multicolumn{1}{c}{ Jenis } & \multicolumn{4}{c}{ Macam Uji Kualitatif } \\
\cline { 2 - 5 } & $\begin{array}{c}\text { Alka- } \\
\text { loid }\end{array}$ & $\begin{array}{c}\text { Flavo } \\
\text {-noid }\end{array}$ & $\begin{array}{c}\text { Ta- } \\
\text { nin }\end{array}$ & $\begin{array}{c}\text { Sapo- } \\
\text { nin }\end{array}$ \\
\hline n-heksana & - & - & - & - \\
Etilasetat & - & + & + & - \\
$\begin{array}{l}\text { Etanol } \\
\text { 96\% }\end{array}$ & - & - & + & - \\
Metanol & - & - & - & + \\
\hline
\end{tabular}

Meditory | ISSN Online : 2549-1520, ISSN Cetak : 2338 - 1159, Vol. 6, No. 2, Desember 2018 HIm. 99 - 107, http://ejournal.poltekkes-denpasar.ac.id/index.php/M 
Kurniawan and Nuniek Ina Ratnaningtyas, Efektivitas Ekstrak Kapang Endofit Isolat BR-S1 (A) Terhadap Bakteri Methicillin-Resistant Staphylococcus aureus (MRSA)

Keterangan : $\quad$ - : tidak terdeteksi

$+:$ terdeteksi

Ekstrak metanol dari kapang endofit isolat BR-S 1 (A) memiliki kemampuan dalam menekan pertumbuhan bakteri MRSA meskipun dengan kekuatan yang lebih rendah jika dibandingkan dengan ekstrak etil asetat. Hasil uji kualitatif menunjukkan bahwa ekstrak metanol memiliki kandungan senyawa saponin (Tabel 3). Metanol merupakan pelarut yang bersifat universal sehingga dapat melarutkan analit yang bersifat polar maupun nonpolar. Beberapa senyawa aktif yang mampu diikat oleh metanol meliputi senyawa alkaloid, steroid, saponin, dan flavonoid ${ }^{9}$. Saponin memiliki kemampuan sebagai senyawa antimikroba dengan mekanisme penyerangan pada membran sitoplasma sehingga sel akan mengalami kematian ${ }^{10}$

Satu-satunya ekstrak kapang endofit isolat $\mathrm{BR}^{-\mathrm{S}_{1}}$ (A) yang tidak memiliki kemampuan dalam menekan pertumbuhan bakteri MRSA adalah ekstrak n-heksana. Ketidakmampuan ekstrak n-heksana tersebut diduga disebabkan oleh tidak adanya kandungan senyawa aktif (Tabel 3) atau meskipun terdapat kandungan senyawa aktif, tetapi senyawa aktif tersebut tidak bersifat antimikroba terhadap bakteri MRSA. Pelarut n-heksana termasuk senyawa nonpolar yang umumnya digunakan untuk ekstraksi minyak atsiri atau terpenoid ${ }^{11}$. Fraksi heksana merupakan fraksi pelarut yang bersifat nonpolar sehingga senyawa yang diujinya berupa senyawa nonpolar seperti terpenoid, minyak atsiri, lemak dan asam lemak ${ }^{12}$. Minyak atsiri ini sering digunakan sebagai zat tambahan dalam sediaan kosmetik, makanan, rokok, dan sebagainya ${ }^{13}$.

Hasil analisis varian (ANAVA) uji sensitivitas ekstrak kapang endofit isolat $\mathrm{BR} \mathrm{S}_{1}$ (A) dengan 4 jenis pelarut yang berbeda terhadap bakteri MRSA menunjukkan perbedaan yang sangat nyata. Hasil analisis menunjukkan nilai $\mathrm{F}$ hitung sebesar 205,2196, sedangkan nilai F tabel pada tingkat kepercayaan $95 \%$ hanya sebesar 3,11 sehingga analisis dilanjutkan dengan Duncan's Multiple Range Test (DMRT). Data hasil uji DMRT menunjukkan bahwa tingkat keefektifan senyawa antimikroba yang dihasilkan dari ekstrak etil asetat berbeda nyata dengan tingkat keefektifan senyawa antimikroba yang dihasilkan dari ekstrak metanol, etanol 96\%, dan n-heksana.

\section{SIMPULAN DAN SARAN}

Berdasarkan hasil dan pembahasan di atas, maka dapat ditarik kesimpulan bahwa dari keempat jenis ekstrak kapang endofit isolat BR-S ${ }_{1}$ (A) asal tumbuhan benalu teh, hanya ekstrak etil asetat saja yang paling efektif dalam menghambat pertumbuhan bakteri MRSA, hal ini karena adanya 
kandungan dua senyawa aktif dari golongan

flavonoid dan tanin.

Perlu dilakukan penelitian lebih lanjut agar dapat diketahui jenis senyawa aktif dari golongan flavonoid dan tanin yang terkandung pada ekstrak etil asetat kapang endofit isolat $\mathrm{BR}-\mathrm{S}_{1}$ (A) asal tumbuhan benalu teh

\section{DAFTAR PUSTAKA}

1. Ikawati, M., A.E. Wibowo, N.S.Octa, dan R. Adelina. Pemanfaatan Benalu Sebagai Antikanker. Fakultas Farmasi, Universitas Gadjah Mada, Yogyakarta, 2008.

http://ccrcfarmasiugm.files.wordpress.co m/2008/06 /paper_benalu_muthi.pdf. Diakses 5 Januari 2014

2. Elfita, Muharni, Munawar and S., Aryani. Secondary Metabolite from Endophytic Fungi Aspergillus niger of the Stem Bark of Kandis Gajah (Garcinia griffithii). Indonesia Journal of Chemistry 2002, 12 (2): 195-200.

3. Jiao, P.Chemical Investigations of Freshwater and Fungicolous Fungi. Dissertation, 2006. University of Iowa. (Unpublished)

4. Sugijanto, N.E., H. Putra., F. Pritayuni., N. Albathaty., dan N.C. Zaini. Daya Antimikroba Ekstrak Lecythophora sp., Endofit yang Diisolasi dari Alyxia reinwardtii. Berkala Penelitian Hayati 2009, $15: 37-44$.

5. Singh, G., and P. Kumar. Phytochemical Study and Screening for Antimicrobial Activity of Flavonoid of Euphorbia hirta. International Journal of Applied and Basic Medical Research 2013, 3(2): 111-116.

6. Tiwari, P., B. Kumar, M. Kaur, G. Kaur, and H. Kaur. 2011. Phytochemical Screening and Extraction: A Review.
Internationale Pharmaceutica Sciencia 2011, 1 (1): 98-106.

7. Cushnie, T.P.T., and A.J. Lamb. Antimicrobial Activity of Flavonoids. International Journal of Antimicrobial Agents 2005, 26: 343-356.

8. Lalitha, T.P. and P. Jayanthi. Preliminary Studies on Phytochemicals and Antimicrobial Activity of Solvent Extracts of Eichhornia crassipes (Mart.) Solms. Asian Journal of Plant Science and Research 2012, 2 (2): 115-122.

9. Astarina, N.W.G., K.W. Astuti, dan N.K. Warditiani. Skrining Fitokimia Ekstrak Metanol Rimpang Bangle (Zingiber purpureum Roxb.). Jurnal Farmasi Udayana 2013, 2 (4): 1-7.

10. Samsumaharto, R.A., dan Y.E. N.I. Sari. Uji Aktivitas Antibakteri Ekstrak nHeksan, Etil Asetat dan Etanol $70 \%$ Daun Rosella (Hibiscus sabdariffa L.) Terhadap Staphylococcus aureus ATCC 25923. Biomedika 2011, 4 (1): 36-42.

11. Elya, B., S. Kosela., dan M. Hanafi. 2009. Senyawa Triterpenoid dari Ekstrak N-heksana Kulit Batang Tanaman Garcinia benthami. Makara Sains 2009, 13 (1): 9-12.

12. Simbala, H.E.I. 2009. Analisis Senyawa Alkaloid Beberapa Jenis Tumbuhan Obat sebagai Bahan Aktif Fitofarmaka. Pasific Jurnal 2009, 1(4): 489-494.

13. Departemen Kesehatan RI. Cara Pembuatan Simplisia. Jakarta: Departemen Kesehatan RI; 1985. 